\title{
Evidence for altered control of glucose disposal after total colectomy
}

\author{
M. Denise Robertson ${ }^{1}$, Geoff Livesey ${ }^{2}$, Shelagh M. Hampton ${ }^{3}$ and John C. Mathers ${ }^{1}$ \\ ${ }^{1}$ Human Nutrition Research Centre, Department of Biological and Nutritional Sciences, University of Newcastle, \\ Newcastle-upon-Tyne NE1 7RU, UK \\ ${ }^{2}$ Institute of Food Research, Colney Lane, Norwich NR4 7UA, UK \\ ${ }^{3}$ School of Biological Science, University of Surrey, Guildford GU2 5XH, UK
}

(Received 5 November 1999 - Revised 9 March 2000 - Accepted 8 May 2000)

\begin{abstract}
Colonic fermentation of organic matter to short-chain fatty acids has been implicated in the improvement in insulin sensitivity achieved by feeding diets rich in complex carbohydrates. The present study assessed the potential role of the colon in determining postprandial glucose kinetics. Metabolic responses to a complex-carbohydrate test meal were determined in conjunction with a primed continuous infusion of $\mathrm{D}-\left[6,6-{ }^{2} \mathrm{H}\right]$ glucose in a group of ileostomists and sex-matched controls. Glucose disposal (GD) was computed using Steele's (1959) nonsteady-state kinetics on a single compartment model. Insulin sensitivity was derived using cumulative GD as the dependent variable, and time and the integrated insulin concentration as independent variables. The ileostomist group had a significantly higher postprandial plasma insulin concentration $(P=0.034)$ compared with the control group, but no difference in the plasma glucose concentration. Total GD was similar in each group, although the insulindependent GD was substantially lower in the ileostomists $(0.46$ v. $0.13 \mathrm{mg}$ glucose $/ \mathrm{min}$ per pmol, $P=0.015$ ). The ileostomist group also showed a $50 \%$ lower rate of glucose oxidation in the postprandial period $(P=0 \cdot 005)$, although the rate of non-oxidative GD was not significantly affected. The present study indicates that loss of the colon is associated with several characteristics of the insulin resistance syndrome, and favours a view that the colon has a role in the control of postprandial glucose.
\end{abstract}

Ileostomy: Glucose disposal: Insulin: Insulin resistance: Stable isotope

Insulin resistance has been postulated to be the underlying factor linking three important conditions: non-insulindependent diabetes mellitus, hypertension, coronary artery disease (Reaven, 1988). These relationships with insulin resistance appear to be mediated to a considerable extent by changes in plasma free fatty acids (FFA). FFA are the preferred energy substrate for tissues, outcompeting glucose in insulin-sensitive tissues (Randle et al. 1963). Diets rich in complex carbohydrates (i.e. starches, NSP and oligosaccharides resistant to small bowel digestion) have been shown to improve insulin sensitivity, an effect which has been attributed to colonic fermentation of organic material to short-chain fatty acids (Wolever et al. 1989; Laurent et al. 1995). Diets rich in fermentable carbohydrate raise plasma acetate levels (Akanji et al. 1989), resulting in a reduction in both FFA and glycerol consistent with its reported anti-lipolytic effects (Crouse et al. 1968). Gutderived propionate may also be implicated, as it has been shown to inhibit gluconeogenesis and stimulate glycolysis in isolated rat hepatocytes (Anderson \& Bridges, 1984) and in man oral propionate lowers both plasma glucose and insulin levels (Venter et al. 1990). The physiological significance of these observations is not known, as gutderived propionate does not reach the peripheral circulation in significant quantities.

In addition, more recent evidence suggests that the postprandial glucose and insulin responses to oral carbohydrate are significantly different in ileostomy patients (Nauck et al. 1996; Hansen et al. 1997; Printz et al. 1998). This phenomenon, combined with the presence of gluco-regulatory hormone-producing cells in the distal gut (Eissele et al. 1992), has highlighted the potential role of the colon as a mediator of carbohydrate metabolism, although its exact role remains to be determined.

The present study was designed to assess quantitatively the role of the colon in postprandial glucose kinetics by

\footnotetext{
Abbreviations: FFA, free fatty acids; GD, glucose disposal; NOGD, non-oxidative glucose disposal; OGD, oxidative glucose disposal.

* Corresponding author: Dr M. Denise Robertson, present address Oxford Lipid Metabolism Group, Nuffield Dept Clinical Medicine, Radcliffe Infirmary, Oxford OX2 6HE, UK, fax +44 1865 224652, email denise.robertson@oxlip.ox.ac.uk
} 
comparing responses of ileostomy patients with those of healthy sex-matched controls to an identical starch-rich meal using stable-isotope kinetics and modelling techniques (Livesey et al. 1998). An effect of the colon on glucose kinetics and the development of insulin resistance would be expected to have consequences for the care of patients undergoing total colectomy, in addition to extending knowledge of the physiological effects of diets rich in starchy foods. Such diets are currently being encouraged as a strategy to improve cardiovascular health by reducing fat intake (Department of Health, 1994).

\section{Materials and methods}

\section{Subjects}

Six male ileostomist subjects who had undergone total colectomy 5-12 years previously for the treatment of ulcerative colitis, each with less than $5 \mathrm{~cm}$ small bowel resection, and six male control subjects participated in the present study. Baseline data for subjects are presented in Table 1. All subjects were healthy and none was currently taking medication. In retrospect, however, it became apparent that the subjects were not as well matched for age and BMI as would have been desirable.

All subjects gave written informed consent and the study was approved by the Joint Ethical Committee of the University of Newcastle and the Newcastle and North Tyneside Health Authorities.

\section{Study protocol}

On the day before the study, subjects were instructed to eat a standardized low-fat evening meal (beans on toast; containing $5.6 \mathrm{~g}$ fat and $145 \mathrm{~g}$ carbohydrate) before fasting overnight $(12-14 \mathrm{~h})$. The next morning subjects were admitted to the Wellcome Research Laboratories, Royal Victoria Infirmary, Newcastle-upon-Tyne, UK. An antecubital cannula and a retrograde distal forearm intravenous cannula were inserted under local anaesthetic (1\% (v/v) lignocaine) into opposing arms. Subjects were given a primed constant infusion of $\mathrm{D}-\left[6,6-{ }^{2} \mathrm{H}\right]$ glucose at time zero via the antecubital cannula, and arterialized blood samples

Table 1. Baseline characteristics of the subjects (Mean values with their standard errors for six subjects)

\begin{tabular}{|c|c|c|c|c|}
\hline \multirow[t]{2}{*}{ Group... } & \multicolumn{2}{|c|}{ Control* $^{*}$} & \multicolumn{2}{|c|}{ lleostomists* } \\
\hline & Mean & SEM & Mean & SEM \\
\hline Age (years) & $42 \cdot 8$ & $6 \cdot 0$ & $51 \cdot 1$ & 3.5 \\
\hline Body weight (kg) & $73 \cdot 1$ & $2 \cdot 9$ & $77 \cdot 7$ & 3.3 \\
\hline BMI $\left(\mathrm{kg} / \mathrm{m}^{2}\right)$ & $23 \cdot 7$ & $1 \cdot 1$ & $25 \cdot 1$ & 0.6 \\
\hline Fasting total cholesterol (mmol/l) & $5 \cdot 0$ & 0.2 & $5 \cdot 6$ & 0.5 \\
\hline Fasting plasma triacylglycerol $(\mathrm{mmol} / \mathrm{l})$ & 1.4 & 0.2 & 1.6 & 0.3 \\
\hline Fasting plasma insulin $(\mathrm{pmol} / \mathrm{l}) \dagger$ & $53 \cdot 3$ & 5.4 & 68.4 & $10 \cdot 2$ \\
\hline Fasting plasma glucose $(\mathrm{mmol} / \mathrm{l}) \dagger$ & $5 \cdot 3$ & 0.2 & $5 \cdot 3$ & 0.2 \\
\hline
\end{tabular}

* Mean values were not significantly different between subject groups (Student's $t$ test for independent samples).

$\dagger$ Mean values determined from measurements taken on three separate occasions. Insulin sensitivity and $\beta$-cell function were assessed using the glucose homeostasis model (Matthews et al. 1985). No statistically significant differences were noted in the fasting state.
Table 2. Composition of the high-complex-carbohydrate test meal ${ }^{\star}$

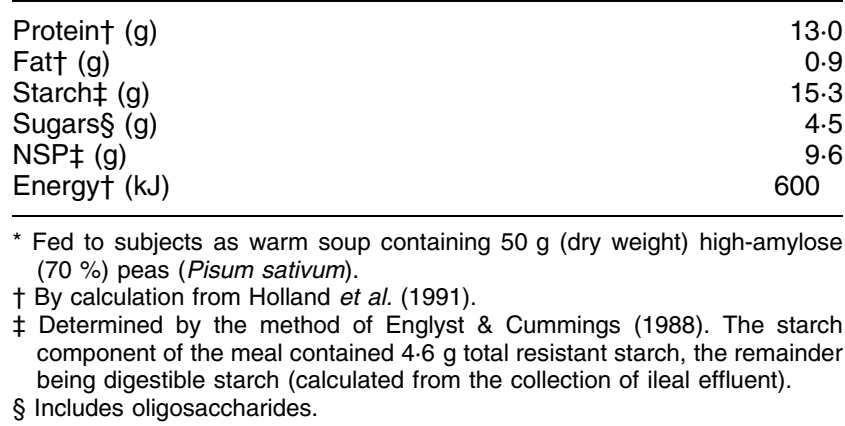

were taken from the distal forearm cannula at regular intervals for $240 \mathrm{~min}$. At $120 \mathrm{~min}$ after the initiation of the tracer infusion, a high-complex-carbohydrate test meal (Table 2) was given to all subjects. Estimates of $\mathrm{O}_{2}$ consumption and $\mathrm{CO}_{2}$ production for $1 \mathrm{~min}$ averaged over 15 min were made on four occasions during the postprandial period using a Deltatrac indirect calorimeter (Datex, Helsinki, Finland; flow rate 40 1/min) calibrated with an $\mathrm{O}_{2}-\mathrm{CO}_{2}$ gas mixture (95:5, v/v; British oxygen company, Guildford, Surrey, UK).

\section{Infusate}

D- $\left[6,6-{ }^{2} \mathrm{H}\right]$ glucose (99 atoms per cent excess) was obtained from MassTrace, Woburn, MA, USA. Pyrogen-free solutions for intravenous infusion were prepared by the pharmacy at Norfolk and Norwich Hospital, Norwich, UK. The priming dose provided $590 \mathrm{mg}$ D-[6,6- $\left.{ }^{2} \mathrm{H}\right]$ glucose in an $11 \mathrm{ml}$ bolus administration and was followed immediately by a continuous infusion of $7 \mathrm{mg} \mathrm{D}$ $\left[6,6-{ }^{2} \mathrm{H}\right] \mathrm{glucose} / \mathrm{min}$ in a volume of $6 \mathrm{ml} / \mathrm{h}$.

\section{Blood analysis}

Whole blood was collected into sodium fluoroxolate, and glucose concentration was measured using the glucose oxidase method with an automated glucose analyser (Beckman Instruments, High Wycombe, Bucks, UK). For insulin and C-peptide assays, blood was collected into KEDTA and all samples were analysed together to avoid inter-batch variation. Insulin concentration was determined in unextracted plasma (Hampton, 1984) using a doubleantibody plus polyethylene glycol radioimmunoassay. Cpeptide concentration was determined in unextracted plasma using a modification of the method published by Heding (1975). Antiserum against human C-peptide was raised by immunizing Soay sheep with synthetic human $\mathrm{C}$ peptide. Hormones assayed exhibited both inter- and intraassay coefficients of less than $10 \%$.

$$
G C-M S
$$

Plasma D-[6,6- $\left.{ }^{2} \mathrm{H}\right]$ glucose samples were prepared for analysis by forming butylboronic acetate derivatives and rediluting in ethyl acetate (Wieko \& Sherman, 1976). Samples were analysed in duplicate using the Hewlett 
Packard MSD system with connecting 5870 series II GC with autosampler (Hewlett Packard, Milton Keyres, Bucks, UK).

\section{Calculations}

Glucose disposal (GD) is the sum of glucose appearance and the balance of its accumulation in the glucose pool. GD was calculated using Steele's (1959) non-steady-state equations for a single-compartment model, as modified by Livesey et al. (1998), with the assumption of an effective volume of glucose distribution of $230 \mathrm{ml} / \mathrm{kg}$ body weight.

Insulin-dependent and -independent glucose disposal. The relationship of GD to insulin concentration was assessed using the formula indicated by Livesey et al. (1998) for each individual separately:

$$
a u c G_{d}(t)=a+b \times a u c[I](t),
$$

where $a u c G_{d}$ is the cumulative area under the curve for total GD (unit weight) reached after each interval of time $(t), a$ is a constant representing an individual's insulinindependent GD rate (the rate apparent for GD at zero insulin concentration), $b$ is a constant representing the rate of change in GD rate with change in insulin concentration (unit weight per unit time and insulin concentration), and $a u c[I](t)$ is the cumulative area under the curve for the insulin concentration reached after each interval of time. Cumulative rates and concentrations were used to overcome problems of possible hysteresis due to the time interval between insulin appearance in plasma and its impact on GD. Changes in the rate of GD due to changes of glucose concentration but independent of insulin concentration are not identifiable.

\section{Statistics}

The time-course of the glucose and hormone responses to the test meal are displayed in the tables as means with their corresponding standard errors. Statistical analysis (ANOVA, was performed on summary data using SPSS version 9.0 (SPSS, Chertsey, Surrey, UK)). The statistical significance of differences between groups was tested using Independent Student's $t$ tests on normally-distributed data. The normal distribution of the data was assessed using the Shapiro-Wilk test.

\section{Results}

\section{Plasma glucose, insulin and C-peptide concentrations}

There were no significant differences in the fasting concentrations or postprandial glucose response between the two subject groups (Fig. 1(a)). The peak glucose concentration was reached approximately $50 \mathrm{~min}$ after the test meal, and values had returned to baseline by the end of the sampling period. Basal insulin concentrations were similar for the two subject groups. The pattern of postprandial insulin response (Fig. 1(b)) followed that of the plasma glucose, with an insulin peak approximately $60 \mathrm{~min}$ after the test meal. In the ileostomist group the maximum insulin concentration reached was significantly
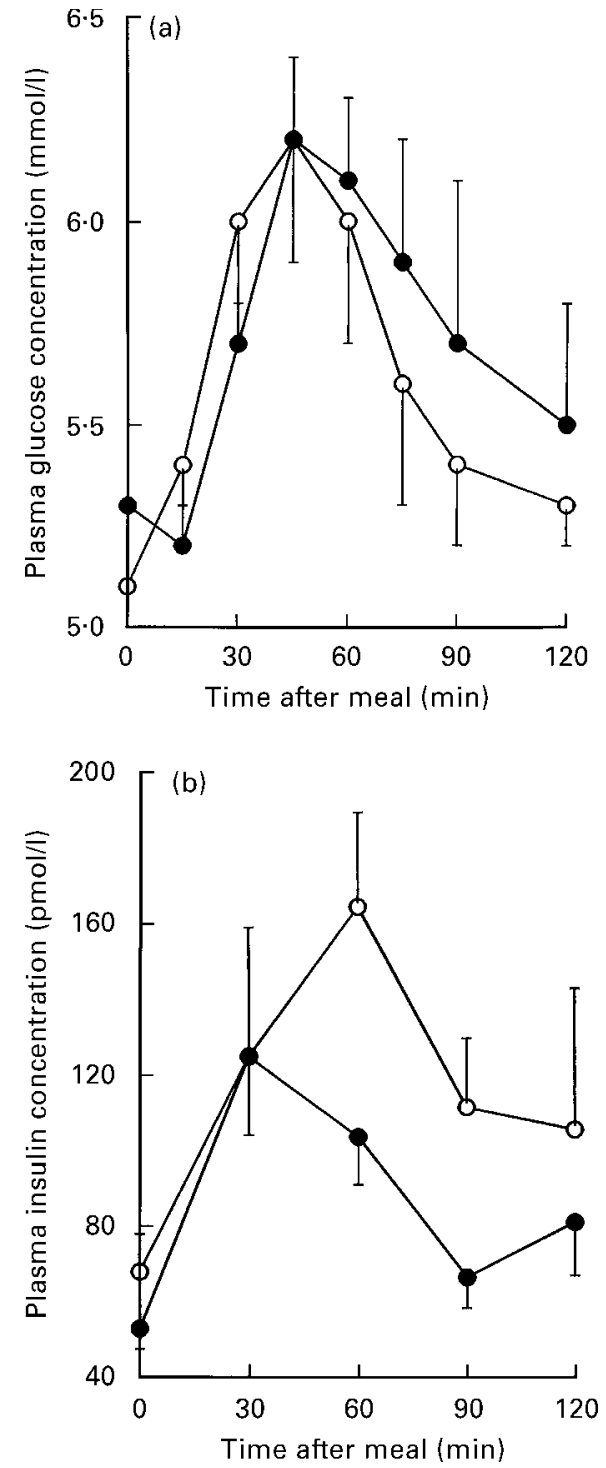

Fig. 1. Postprandial plasma glucose (a) and insulin (b) responses in control $(\bullet)$ and ileostomist $(O)$ subjects after a high-complexcarbohydrate test meal. Values are means with their standard errors represented by vertical bars for six subjects. For details of procedures, see p. 814 .

higher than that in the control group (240 v. $138 \mathrm{pmol} / \mathrm{l}$, $P=0.034)$. The pattern of C-peptide release following the test meal mirrored that of the plasma insulin response, with peak levels reached after approximately $60 \mathrm{~min}$. A higher maximal value was attained by the ileostomist group (Table 3 ), although this difference from controls did not reach conventional statistical significance $(P=0.063)$. By 120 min after the test meal the C-peptide concentration was still elevated at approximately 1.5 times the basal values (1267 and $1351 \mathrm{pmol} / \mathrm{l}$ for control and ileostomist groups respectively).

\section{Glucose disposal}

There was no difference in the total GD between subject 
Table 3. Plasma glucose, insulin and C-peptide concentrations in control and ileostomist subjects before and after a high-complexcarbohydrate test meal $\dagger$

(Mean values with their standard errors for six subjects)

\begin{tabular}{|c|c|c|c|c|}
\hline \multirow[t]{2}{*}{ Group... } & \multicolumn{2}{|c|}{ Control } & \multicolumn{2}{|c|}{ Ileostomists } \\
\hline & Mean & SEM & Mean & SEM \\
\hline \multicolumn{5}{|l|}{ Glucose } \\
\hline Basal (mmol/l) & $5 \cdot 1$ & $0 \cdot 16$ & $5 \cdot 3$ & 0.09 \\
\hline Peak (mmol/l) & $6 \cdot 2$ & 0.38 & 6.5 & 0.29 \\
\hline AUC (mmol/l.120 min) & 678 & 32 & 706 & 31 \\
\hline \multicolumn{5}{|l|}{ Insulin } \\
\hline Basal (pmol/l) & 53 & 5 & 68 & 10 \\
\hline Peak (pmol/l) & 139 & 19 & $240^{\star}$ & 37 \\
\hline AUC (nmol/l.120 min) & $10 \cdot 8$ & 0.9 & $14 \cdot 6^{*}$ & 1.9 \\
\hline \multicolumn{5}{|l|}{ C-peptide } \\
\hline Basal (pmol/l) & 756 & 50 & 881 & 81 \\
\hline Peak (pmol/l/) & 1690 & 240 & 2000 & 220 \\
\hline AUC (nmol//.120 min) & 149 & 20 & 158 & 15 \\
\hline AUC C-peptide:AUC insulin & 14.5 & $1 \cdot 6$ & $12 \cdot 5$ & $2 \cdot 1$ \\
\hline
\end{tabular}

AUC, area under the curve.

Mean values were significantly different from those of the control group: ${ }^{*} P \leq 0.05$.

† For details of the test meal and procedures, see Table 2 and p. 814.

groups (Table 4). However, the control subjects had an insulin-dependent GD rate, when estimated as described by Livesey et al. (1998), that was approximately four times that of the ileostomists group. In contrast, estimates of the insulin-independent GD rate obtained by the same derivation did not differ significantly between groups. The oxidative (OGD) and non-oxidative (NOGD) GD rates were calculated from the non-protein RQ equations of Jéquier et al. (1987) using $\mathrm{CO}_{2}$ output and $\mathrm{O}_{2}$ intake values obtained experimentally from indirect calorimetry. In both subject groups the NOGD was the greater component. OGD was approximately twice as great for the controls as for the ileostomists $(P \leq 0 \cdot 01)$. There was no statistically significant difference between groups for the absolute rate of NOGD.

\section{Discussion}

Abnormalities in glucose metabolism are central to hypotheses concerning the development of diabetes, obesity and cardiovascular disease (Reaven, 1988). Quantitative investigations of glucose metabolism employing modelling techniques and data obtained using stable isotopes are rapidly becoming established as reliable methods for investigating substrate kinetics under physiological conditions. We believe that such non-invasive techniques should be encouraged. The single-compartment model approach first developed by Steele (1959), with its subsequent modification (for review, see Livesey et al. 1998), was used in the present study to determine the quantitative consequences of colectomy for glucose kinetics following a test meal rich in complex carbohydrate. Such an approach was designed to investigate the importance of the large bowel as a modifier of whole-body glucose kinetics.

There were no statistically significant differences between control subjects and ileostomists in peak glucose concentration, area under the curve for glucose or GD after ingestion of the test meal, which suggests that short-term $(2 \mathrm{~h})$ glycaemic responses to this food were unaltered by the absence of the colon. This finding is in contrast to observations of higher postprandial plasma glucose concentrations in ileostomists compared with controls when the test meal contained an aqueous glucose solution (Hansen et al. 1997; Robertson \& Mathers, 2000). Such differences in glycaemia in ileostomists after oral glucose could potentially be explained by decreases in circulating glucagon-like peptide 1 concentrations (Vaag et al. 1996). However, in the present study the consumption of peas (Pisum sativum) as the source of carbohydrate had no effect on plasma glucagon-like peptide 1 concentrations within the time scale of the present study. Gut-hormone measurements were undertaken in the present study and have been published previously (Robertson et al. 1999). Although there was no detectable difference in glycaemia between the subject groups, the higher peak plasma insulin concentration in ileostomists may represent a change in B-cell function or in peripheral tissue sensitivity to insulin. The C-peptide concentration, although higher in the ileostomist group, failed to reach conventional significance $(P=0.063)$. C-peptide can be regarded as a more accurate indicator of endogenous insulin secretion than peripheral insulin concentration (Madsbad et al. 1983) as up to $50 \%$ of the insulin is extracted by the liver. There was no difference in $\mathrm{C}$-peptide:insulin between the two subject

Table 4. Estimates of postprandial glucose disposal† (GD) in control and healthy ileostomist subjects after a high complex-carbohydrate-test mealł

(Mean values with their standard errors for six men)

\begin{tabular}{|c|c|c|c|c|}
\hline \multirow{2}{*}{ Group... } & \multicolumn{2}{|c|}{ Control } & \multicolumn{2}{|c|}{ Ileostomists } \\
\hline & Mean & SEM & Mean & SEM \\
\hline Total GD (g) & 43.4 & $5 \cdot 3$ & $40 \cdot 1$ & 1.4 \\
\hline Insulin-dependent GD (mg glucose/min per pmol insulin) & 0.456 & 0.107 & $0 \cdot 126^{*}$ & 0.031 \\
\hline Insulin-independent GD (mg glucose/min) & 195 & 155 & 230 & 102 \\
\hline Oxidative GD: $\mathrm{g}$ \% total & $\begin{array}{l}18 \cdot 5 \\
46 \cdot 8\end{array}$ & $2 \cdot 2$ & $\begin{array}{l}9 \cdot 7^{\star *} \\
24 \cdot 2\end{array}$ & 0.8 \\
\hline Non-oxidative GD: $\mathrm{g}$ \% total & $\begin{array}{l}24 \cdot 9 \\
53 \cdot 2\end{array}$ & $6 \cdot 0$ & $\begin{array}{l}30 \cdot 4 \\
75 \cdot 8^{\star}\end{array}$ & $1 \cdot 8$ \\
\hline
\end{tabular}

Mean values were significantly different from those of the control group: ${ }^{\star} P \leq 0.05,{ }^{\star \star} P \leq 0.01$.

$\dagger$ Calculated using the non-steady-state equations of Steele (1959) for a single-compartment model as modified by Livesey et al. (1998).

$\ddagger$ For details of test meal and procedures, see Table 2 and p. 814. 


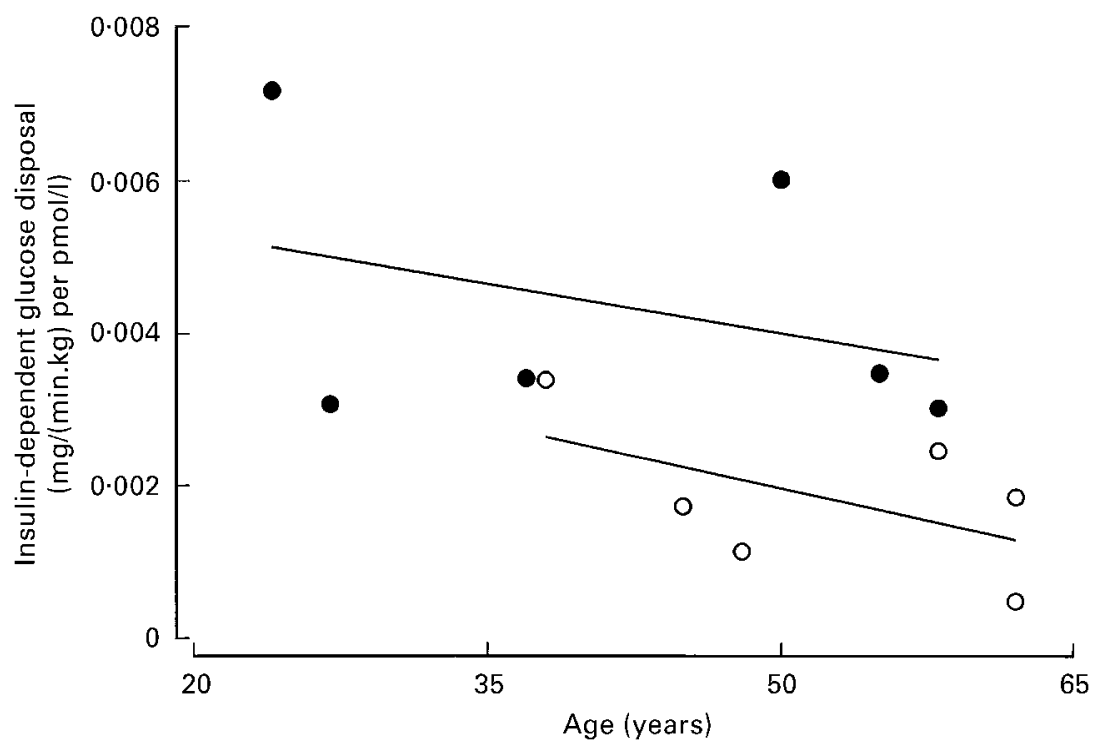

Fig. 2. Relationship between age and insulin-dependent glucose disposal (adjusted for body weight) in control $(\bullet)$ and ileostomist $(O)$ subjects after a high-complexcarbohydrate test meal (for controls $y=-4 \cdot 3 e^{-5} x+0.0061, r 0.356$; for ileostomists $\left.y=-5.6 \mathrm{e}^{-5} \mathrm{x}+0.0049, r 0.553\right)$. The interaction between age and group was not significant $(P=0.363)$. For details of procedures, see p. 814 .

groups, which indicates that the observed increase in peak insulin concentration in the ileostomist group was not due to a decreased rate of insulin clearance (Table 3). This finding strengthens the argument for greater insulin resistance in the ileostomist group.

The rate of insulin-dependent GD for control subjects in the present study $(0.46 \mathrm{mg}$ glucose/min per pmol insulin) was similar to that reported for a group of healthy adult controls $(0.5 \mathrm{mg}$ glucose/min per pmol insulin) by Livesey et al. (1997). Insulin-dependent GD by ileostomists in the present study was only $28 \%(P=0.017)$ of that observed for the control subjects. Part of this difference might be due to the fact that, on average, the ileostomists were 10 years older than the controls, and ageing has been associated with a reduction in insulin production (Davidson, 1979), insulin clearance (Reaven et al. 1982) and insulin sensitivity (Miyazaki et al. 1998). In both study groups insulin sensitivity declined with age (Fig. 2), but the insulindependent GD rate in the ileostomist group was consistently lower than that for controls, even when the effects of age were taken into account. It should also be noted that although the subjects were not exactly matched for age in the present study, differences in the glycaemic response in ileostomists have been noted in other studies, apparently independent of the age effect (Hansen et al. 1997; Robertson \& Mathers, 2000).

In the postprandial state, uptake by muscle is the major pathway for insulin-dependent GD (Young et al. 1988). Glucose uptake into the muscle cell is dependent on membrane transport and glucose phosphorylation by hexokinase; in vivo, the activity of both processes have been found to be decreased by raised circulating concentrations of FFA (Randle et al. 1963). Due to a loss of blood samples, no FFA measurements are available for the present study. However, plasma glucagon concentrations were elevated in the ileostomists after consumption of the pea-containing test meal (Robertson et al. 1999) and glucagon has been shown to be more potent than FFA in reducing insulin-dependent glucose transport (Chambrier et al. 1990).

The separation of GD into OGD and NOGD components provides important additional information. In normal subjects undertaking an oral glucose tolerance test, $55 \%$ of the glucose uptake has been reported to occur via NOGD and $45 \%$ via OGD (Meyer et al. 1980). These values are very similar to those obtained for our control group (Table 4). In the ileostomist group, however, there were significant reductions in the absolute OGD $(P \leq 0.01)$ and in the proportion of the total GD which followed OGD pathways $(P \leq 0 \cdot 05)$. Changes in OGD are believed to be secondary to substrate switching (Randle et al. 1963), and it has been demonstrated that by maintaining a high plasma FFA concentration (by concomitant intralipid and heparin infusion), OGD can be reduced by $40 \%$ without any change in NOGD (Vaag et al. 1994), a finding similar to that observed in our ileostomist group. Unfortunately, FFA measurements are not available from the present study and, due to the limited information in the literature referring to postprandial FFA levels in ileostomists, it still remains to be determined whether lipid levels in colectomized patients are an important factor in the apparently decreased insulin sensitivity and glucose oxidation.

The present preliminary study of whole-body glucose kinetics following total colectomy suggests a potentially important role for the colon in postprandial glucose metabolism. Ileostomists exhibited some characteristics of the insulin resistance syndrome, including an elevation in the postprandial insulin response and a decrease in both the insulin-dependent GD and glucose oxidation rate. However, the number of subjects studied was limited, and the 
two groups were not as well matched as is desirable. Further studies are required to confirm the present observations. To our knowledge there is no information available on the relative risks of diabetes and cardiovascular disease following total colectomy, as epidemiological studies have so far concentrated on post-operative complications. This lack of data represents an important gap in our understanding, which may be important in light of the present data. It also remains to be established by additional experiments how the colon modulates whole-body insulin sensitivity, and whether it is possible to enhance this role by dietary, pharmacological or other means.

\section{Acknowledgements}

The authors would like to thank Dr Vipin Mishra and Dr Mark Walker of the Wellcome Research Laboratories, Royal Victoria Infirmary, Newcastle for medical cover during clinical procedures, and the members of the Northern Branch of the Ileostomy Association who were central to this research project. M. D. R. held a BBSRC Case Award. The work was also supported by a grant from the Ministry of Agriculture, Fisheries and Food.

\section{References}

Akanji AO, Bruce MA \& Frayn KN (1989) Effect of acetate infusion on energy expenditure and substrate oxidation rates in non-diabetic and diabetic subjects. European Journal of Clinical Nutrition 43, 107-115.

Anderson JW \& Bridges SR (1984) Short-chain fatty acid fermentation products of plant fiber affect glucose metabolism of isolated rat hepatocytes. Proceedings of the Society for Experimental Biology and Medicine 177, 372-376.

Chambrier C, Picard S, Vidal H, Cohen R, Riou JP \& Beylot M (1990) Interactions of glucagon and free fatty acids with insulin in control of glucose metabolism. Metabolism 39, 976-984.

Crouse JR, Gerson CD, DeCarli LM \& Lieber CS (1968) Role of acetate in the reduction of plasma free fatty acids produced by ethanol in man. Journal of Lipid Research 9, 509-512.

Davidson M (1979) The effect of ageing on carbohydrate metabolism: a review of the English literature and a practical approach to the diagnosis of diabetes mellitus. Metabolism 28, 688-705.

Department of Health (1994) Nutritional Aspects of Cardiovascular Disease. Report on Health and Social Subjects no. 46. London: HM Stationery Office.

Eissele R, Goke R, Willemer S, Harthus HP, Vermeer H, Arnold R \& Goke B (1992) Glucagon-like peptide-1 in cells in the gastrointestinal tract and pancreas of rat, pig and man. European Journal of Clinical Investigation 22, 283-291.

Englyst HN \& Cummings JH (1988) An improved method for the measurement of dietary fibre as non-starch polysaccharides in plant foods. Journal of the Association of Official Analytical Chemists 71, 808-814.

Hampton SM (1984) C-peptide of proinsulin: its diagnostic use and a possible physiological role. PhD Thesis, University of Surrey.

Hansen CP, Andreasen JJ \& Holst JJ (1997) The release of gastric inhibitory peptide, glucagon-like peptide 1 and insulin after oral glucose test in colectomized subjects. Scandinavian Journal of Gastroenterology 32, 473-477.

Heding LG (1975) Radioimmunological determination of human C-peptide in serum. Diabetologia 11, 541-548.
Holland B, Welch AA, Urwin ID, Buss DH, Paul AA \& Southgate DAT (1991) McCance and Widdowson's The Composition of Foods. 5th ed. London: RSC/MAFF.

Jequier E, Acheson K \& Schutz Y (1987) Assessment of energy expenditure and fuel utilization in man. Annual Review of Nutrition 7, 187-208.

Laurent C, Simoneau C, Marks L, Braschi S, Champ M, Charbonnel B \& Krempf FM (1995) Effect of acetate and propionate on fasting hepatic glucose production in humans. European Journal of Clinical Nutrition 49, 484-491.

Livesey G, Faulks R, Wilson P, Brown J, Roe M, Newman T, Taylor K, Hampton S \& Greenwood R (1997) Postprandial insulin sensitivity of glucose disposal measured with $\left[6,6^{2} \mathrm{H}\right]-\mathrm{D}-$ glucose is markedly dependent on prior meal consumption. Proceedings of the Nutrition Society 56, 38A.

Livesey G, Wilson PDG, Dainty JR, Brown JC, Faulks RM, Roe MA, Newman TA, Eagles J, Mellon FA \& Greenwood RH (1998) Simultaneous time-varying systematic appearance of oral and hepatic glucose in adults monitored with stable isotopes. American Journal of Physiology 275, E717-E728.

Madsbad S, Kehlet H, Hilsted J \& Tronier B (1983) Discrepancy between plasma C-peptide and insulin response to intravenous glucose. Diabetes 32, 436-438.

Matthews DR, Hosker JR, Rudenski AS, Naylor BA, Treacher TF \& Turner RC (1985) Homeostasis model assessment: insulin resistance and B-cell function from fasting plasma glucose and insulin concentrations in man. Diabetologia 28, 412-419.

Meyer HU, Curchod B, Maeder F, Pachud P, Jequier E \& Felber JP (1980) Modifications of glucose storage and oxidation in nonobese diabetics, measured by continuous indirect calorimetry. Diabetes 29, 752-756.

Miyazaki Y, Hirata A, Murakami H, Fukuoka M, Agata J, Higashiura K, Masuda A, Ura N \& Shimamoto K (1998) Effects of aging on the insulin actions for the glucose metabolism and renal function in normotensives and essential hypertensives. American Journal of Hypertension 11, 10561064.

Nauck MA, Siemsgluss J, Orskov C \& Holst JJ (1996) Release of glucagon-like peptide 1(GLP-1[7-36 amide]), gastric inhibitory polypeptide (GIP) and insulin in response to oral glucose after upper and lower intestinal resections. Zeitschrift fur Gastroenterologie 34, 159-166.

Printz H, Reiter S, Samedi N, Ebrahimsade S, Kirchner R, Arnold R \& Goke B (1998) GLP-1 release in man after large bowel resection or intrarectal glucose administration. Digestion 59, 689-695.

Randle PJ, Garland PB \& Hales CN (1963) The glucose-fatty acid cycle. Its role in insulin sensitivity and the metabolic disturbances of diabetes mellitus. Lancet i, 785-789.

Reaven GM (1988) Role of insulin resistance in human disease. Diabetes 37, 1595-1607.

Reaven G, Greensfield M \& Mondon C (1982) Does insulin removal rate from the plasma decline with age? Diabetes $\mathbf{3 1}$, 670-673.

Robertson MD, Livesey G, Morgan LM, Hampton SM \& Mathers JC (1999) The influence of the colon on postprandial glucagon-like peptide (7-36) amide concentration in man. Journal of Endocrinology 161, 25-31.

Robertson MD \& Mathers JC (2000) Gastric emptying rate of solids is reduced in a group of ileostomists. Digestive Diseases and Sciences 45, 1287-1294.

Steele R (1959) Influence of glucose loading and of injected insulin on hepatic glucose output. Annals of the New York Academy of Sciences 82, 420-430.

Vaag AA, Handberg A, Skott P, Richter EA \& Beck-Nielsen H (1994) Glucose-fatty acid cycle operates in humans at the levels of both whole body and skeletal muscle during low and 
high physiological plasma insulin concentrations. European Journal of Endocrinology 130, 70-79.

Vaag AA, Holst JJ, Volund A \& Beck-Nielsen H (1996) Gut incretin hormones in identical twins discordant for non-insulin dependent diabetes mellitus (NIDDM) - evidence for decreased glucagon-like peptide 1 secretion during oral glucose ingestion in NIDDM twins. European Journal of Clinical Endocrinology 135, 425-432.

Venter CS, Vorster HH \& Cummings JH (1990) Effect of dietary propionate on carbohydrate and lipid metabolism in healthy volunteers. American Journal of Gastroenterology 85, 549553.
Wieko J \& Sherman WR (1976) Boroacetylation of carbohydrates. Correlations between structure and mass spectral behaviour in monoacetylhexose cyclic boronic esters. Journal of the American Chemical Society 98, 7631-7637.

Wolever TMS, Brighenti F, Royall D, Jenkins AL \& Jenkins DJA (1989) Effect of rectal infusion of short chain fatty acids in human subjects. American Journal of Gastroenterology 84, 1027-1034.

Young AM, Bogardus C, Stone K \& Mott DM (1988) Insulin response of components of whole body and muscle carbohydrate metabolism in humans. American Journal of Physiology 254, E231-E236. 